\title{
Application of Radiofrequency for Decolorization, Floc Formation, and Microorganism Inactivation
}

\author{
Javad Yahaghi, Alireza Bazargan* \\ School of Environment, College of Engineering, University of Tehran, Iran \\ *Correspondence: $\underline{\text { alireza.bazargan@ut.ac.ir }}$
}

SUBMITTED: 3 December 2021; REVISED: 3 January 2022; ACCEPTED: 5 January 2022

\begin{abstract}
The use of radio frequency for water and wastewater treatment is a topic that has not been extensively explored. In this study, the effect of a HydroFlow S38 device (Hydropath Holdigs) inducing $150 \mathrm{KHz}$ radio frequency (RF) has been investigated, removing color, forming coagulant flocs and their sedimentation, and the removal of bacteria. Experiments were first conducted on synthetic samples, and then on landfill leachate from the Aradkooh waste processing and landfilling complex (Kahrizak) in Tehran, Iran. The results of the experiments showed that RF had little to no effect on de-coloring in the absence or presence of sodium hypochlorite. Also, the coagulation and flocculation of ferric chloride remained unaffected. However, the use of RF was shown to reduce the number of bacteria significantly. The inductance of RF alone, without any other aid or chemical/physical treatment, was able to reduce the bacterial count by $35 \%$. These findings provide motivation for future research regarding the use of RF for bacteria inactivation.
\end{abstract}

KEYWORDS: Radio frequency treatment; floc settling; color removal; disinfection

\section{Introduction}

Landfill leachate (LFL) management is one of the main challenges at MSW landfill sites [1]. Leachate is the liquid that forms in the landfill and has both soluble and suspended solids in its composition [2]. Whenever the water content of the landfill exceeds its field capacity, whether due to the infiltration of external water into the landfill, compaction of the waste, or any other reason, the excess water flows through the waste and forms the leachate. Due to the variety of wastes in landfills, the composition of LFL is very complex and changeable, which creates treatment problems [3].

One of the concerns about LFL treatment is the existence of various contaminants, with concentrations varying from place to place and time to time [4]. Landfill age and waste composition are the two main factors that affect the LFL composition and concentration of contaminants [5]. Therefore, landfill sites are often categorized based on the age of the waste: young landfills (less than 5 years old), intermediate landfills (5 to 10 years old), and old landfills (more than 10 years old). Table 1 provides some characteristics of LFL according to the age of the landfill [6]. So far, several methods have been developed for LFL treatment [7], including physical treatment (such as adsorption [8] and filtration [9], chemical treatment (such as chemical oxidation [10] and biological treatment (such as using membrane bioreactors) [11] 
and sequencing batch reactors [12]. Each of these methods has their own advantages and disadvantages, but none of them can treat LFL alone [13].

Table 1. Some leachate characteristics based on landfill age [14].

\begin{tabular}{cccc}
\hline Parameters & Young & Intermediate & Old \\
\hline Age $($ years $)$ & $<5$ & $5-10$ & $>10$ \\
pH & $3-7$ & $6-8$ & $>7.5$ \\
COD $(\mathrm{mg} / \mathrm{l})$ & $4000-90,000$ & $1000-30,000$ & $<3000$ \\
BOD $(\mathrm{mg} / \mathrm{l})$ & $2000-50,000$ & $500-15,000$ & $<300$ \\
BOD/COD & $0.5-1$ & $0.1-0.5$ & $<0.1$ \\
TOC/COD & $<0.3$ & $0.3-0.5$ & $>0.5$ \\
Biodegradability & High & Medium & Low \\
\hline
\end{tabular}

In the current study, the effect of radio-frequency (RF) inductance on LFL and some of its characteristics has been investigated. Using RF treatment can be considered a kind of physical treatment. In physical methods, in contrast to chemical methods, no chemicals will be added and no chemical reactions are expected; hence, physical methods can often be environmentallyfriendly.

According to a review of the literature on treating fluids with RF, the most common areas of research appear to be prevention of fouling and scale formation in plumbing tubes and heat exchangers [15-18]; prevention of scale formation or corrosion of oilfield extraction wells [19], [20]; control and killing of bacterial biofilms [18], [21]; and treatment of dye-containing wastewater [22].However, to the best of the authors' knowledge, the effect of RF inductance on LFL has not been studied yet. More specifically, this study has the following three objectives: (i) evaluate the effect of RF inductance on decolorization; (ii) evaluate the effect of RF inductance on coagulation and settling of coagulant flocs; and (iii) evaluate the effect of RF inductance on reduction of bacterial count.

\section{Materials and Methods}

In this study, an S38-type HydroFlow (HF) device, developed by Hydropath Holdings, was used in order to induce RF into the liquid in the system. The HF device was generously provided to the research group by Radin Gostar Sina (rgspath.com), the producer's official representative in Iran. The working voltage of the HF is $1.2 \mathrm{~V}$ and it can easily be installed on any type of plastic or metal tube with a diameter of up to 1.25 inches $(38 \mathrm{~mm})$. The HF device is capable of generating and inducing RFs with frequencies between 120 and $200 \mathrm{kHz}$.

All of the experiments were carried out in a system composed of a $12 \mathrm{~L}$ container, circular plumbing, a semi-immersed pump, a flow-off button, and a sampling valve (Figure 1). By installing the HF on the plumbing and turning it on, RF will be induced into the circulating liquid in the system, and by comparing the characteristics of the liquid after treatment with the baseline scenario (absence of HF), the effect of RF inductance can be discerned. Circulating the liquid in the system ensures that all of the liquid has been subjected to the RF without any dead spots. Initially, the experiments were carried out on synthetic waste, followed by the treatment of LFL from the Aradkooh waste processing and landfill complex (Kahrizak). 


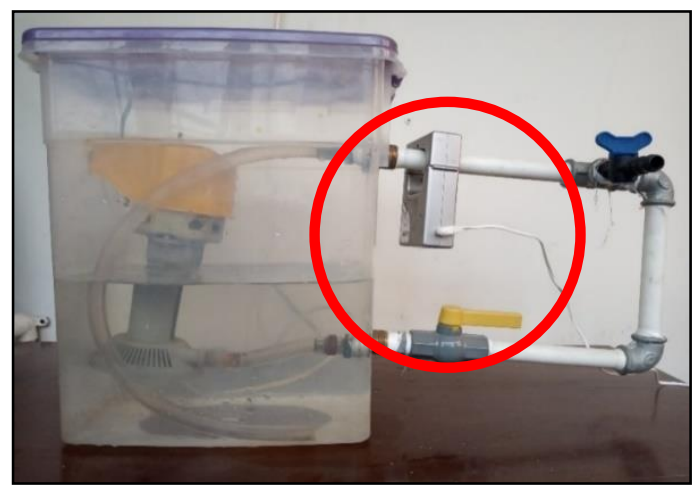

Figure 1. The experimental setup used in this study. The HF device is shown with the red circle.

\subsection{The effect of RF inductance on decolorization}

A combination of tap water and black calligraphy ink was used as synthetic wastewater in decolorization experiments. Light absorption of the liquid in the visible wavelength range (400 to $700 \mathrm{~nm}$ ) was used to measure any changes in the variation in dye concentration. For the first set of experiments, $7 \mathrm{~L}$ of tap water was mixed with $0.6 \mathrm{~mL}$ of black ink in the system. After turning the pump on, the solution circulated for $1 \mathrm{~min}$ in the system without induction. At that moment, a sample was taken from the solution as a representative of the baseline scenario. Then, the HF was turned on and the solution was exposed to RF for about $90 \mathrm{~min}$. After 90 min, another sample was taken from the solution as a representative of the RF-aided scenario. Finally, the light absorption of both samples was measured with a DR5000 spectrophotometer and compared with each other.

In the second set of experiments, the effect of RF inductance on de-coloring in tandem with $\mathrm{NaClO}$ ( $5 \%$ purity) was investigated. The aim of this experiment was to see if $\mathrm{RF}$ inductance could enhance the decolorization performance of the bleaching chemical. In this experiment, a system with the ability to adjust dosing rate was used for the continuous injection of liquid $\mathrm{NaClO}$. For the experiment, $7 \mathrm{~L}$ of solution with $0.35 \mathrm{ml}$ of ink was allowed to circulate in the system for 1 minute. A sample was then taken before the $\mathrm{NaClO}$ solution was injected at a rate of $4 \mathrm{ml} / \mathrm{s}(240 \mathrm{ml} / \mathrm{min})$. Samples were taken at 5 -minute intervals. Next, the same procedure was repeated, but this time the HF was turned on during the experiment. Because of the high reactivity of $\mathrm{NaClO}$, the taken samples were introduced to the spectrophotometer immediately after sampling. Here, in addition to measuring light absorption of the solution in the visible wavelength range, the 200 to $400 \mathrm{~nm}$ range was also investigated. It should be noted that measuring light absorption in the visible and UV ranges requires their own cells, as shown in Figure 2.

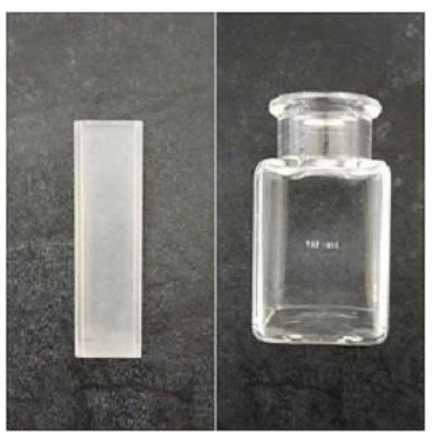

Figure 2. Cells for light absorption measurement with the spectrophotometer (left: UV cell, right: visible cell). 


\subsection{The effect of RF inductance on coagulant floc settling}

In this part of the study, the possible effect of $\mathrm{RF}$ on $\mathrm{FeCl}_{3}$ (40\% purity) floc formation and settling were investigated. $\mathrm{Ca}(\mathrm{OH}) 2$ powder (95\% purity) or $\mathrm{NaOH}(12.5 \%$ purity) were used to adjust the $\mathrm{pH}$ of the solution. The experiments were carried out at 3 different $\mathrm{pH}$ values of 5,6 and 7.

First, $7 \mathrm{~L}$ of tap water was poured into the system and the pump was turned on. After one minute, a predetermined amount of $\mathrm{FeCl}_{3}$ was injected into the water. The resulting solution was circulated in the system for another $4 \mathrm{~min}$. Then, the determined amount of alkaline material was added to the solution. The final solution was circulated in the system for 5 minutes. After that, the pump was turned off and the gradual sedimentation of suspended solids was recorded by a camera for $30 \mathrm{~min}$. The same procedure was repeated with and without the HF device turned on. It should be noted that the depth and height of the container were graduated so that the thickness of the sludge blanket from the bottom of the container could be measured at any time. Tables 2 and 3 show the details of the conducted experiments.

Table 2. Experimental runs with $95 \%$ purity $\mathrm{Ca}(\mathrm{OH})_{2}$ used as the alkali for adjusting $\mathrm{pH}$.

\begin{tabular}{cccccc}
\hline Materials & Water $(\mathbf{L})$ & $\mathbf{F e C l}_{\mathbf{3}}(\mathbf{m l})$ & $\mathbf{C a}(\mathbf{O H})_{\mathbf{2}}(\mathbf{g})$ & $\mathbf{H F}$ device & $\mathbf{p H}$ value \\
\hline \multirow{2}{*}{ First Exp. } & 7 & 42 & 30 & Off & 7 \\
& 7 & 42 & 30 & On & 7 \\
Second Exp. & 7 & 42 & 25 & Off & 6.05 \\
& 7 & 42 & 25 & On & 6.05 \\
Third Exp. & 7 & 42 & 20 & Off & 5.2 \\
& 7 & 42 & 20 & On & 5.2 \\
Forth Exp. & 7 & 15 & 9 & Off & 7.6 \\
& 7 & 15 & 9 & On & 7.6 \\
Fifth Exp. & 7 & 15 & 8 & Off & 6.6 \\
& 7 & 15 & 8 & On & 6.6 \\
Sixth Exp. & 7 & 15 & 7 & Off & 5.5 \\
& 7 & 15 & 7 & On & 5.5 \\
\hline
\end{tabular}

Table 3. Experimental runs with $12.5 \%$ purity $\mathrm{NaOH}$ used as the alkali for adjusting $\mathrm{pH}$.

\begin{tabular}{cccccc}
\hline Materials & Water $(\mathbf{L})$ & $\left.\mathbf{F e C l}_{\mathbf{3}} \mathbf{( m l}\right)$ & $\mathbf{N a O H}(\mathbf{m l})$ & HF device & pH value \\
\hline \multirow{2}{*}{ First Exp. } & 7 & 15 & 30 & Off & 7 \\
& 7 & 15 & 30 & On & 7 \\
\multirow{2}{*}{ Second Exp. } & 7 & 25 & 25 & Off & 6 \\
\multirow{2}{*}{ Third Exp. } & 7 & 25 & 25 & On & 6 \\
& 7 & 20 & 20 & Off & 5 \\
\end{tabular}

\subsection{Landfill leachate sampling and experiments}

After conducting experiments on synthetic wastewater, leachate was sampled from the Aradkooh waste processing and landfilling complex (Kahrizak), located in southern Tehran, Iran. Since one of the objectives of this study was to evaluate the effect of RF inductance on the bacterial community, samples were taken from young leachate with high bacterial activity. The coordinates of the sampling point were $35^{\circ} 27^{\prime} 42.6^{\prime \prime}$ latitude and 51 $20^{\prime} 21.0^{\prime \prime}$ longitude (Figure 3). Leachate samples were stored in a refrigerator at $4{ }^{\circ} \mathrm{C}$ as soon as possible in order to prevent decay, biological activity, or alteration in the properties as much as possible. 


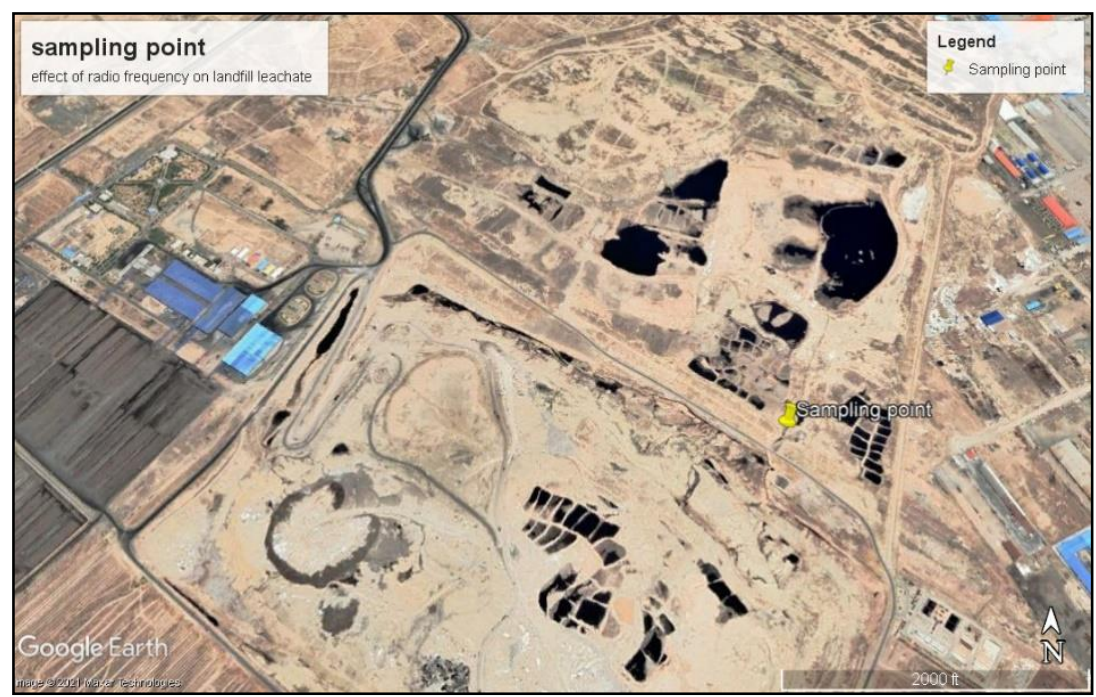

Figure 3. Landfill leachate sampling point (coordinates: $35^{\circ} 27^{\prime} 42.6^{\prime \prime}$ latitude and $51^{\circ} 20^{\prime} 21.0^{\prime \prime}$ longitude).

To begin the LFL treatment, $6 \mathrm{~L}$ of the sample were poured into the system and the pump was activated.After one minute, two samples were taken as a representative of the raw leachate, one for measuring bacterial count and one for measuring $\mathrm{pH}, \mathrm{EC}$, and color. The sample related to the bacterial count was immediately put in a bucket containing ice and water in order to stop further biological activity as much as possible. After one minute of turning the pump on, the HF device was also turned on. Subsequent samples were taken at $15 \mathrm{~min}, 45 \mathrm{~min}$, and 75 min after turning the HF on. After 75 minutes, the pump was turned off while the HF was still on. Another sample was taken 10 minutes after turning the pump off to measure $\mathrm{pH}$, $\mathrm{EC}$, and color. Because of the strength of the color of the leachate, the samples were diluted 1:1 with distilled water so that the spectrophotometer could measure the light absorption without error. The experimental steps are shown in Figure 4.

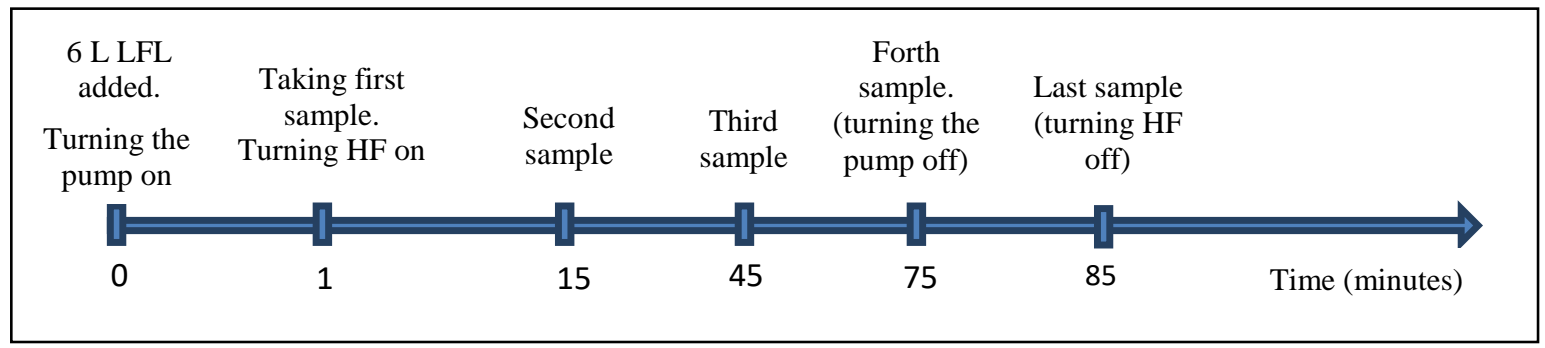

Figure 4. Experimental steps to evaluate the effect of RF inductance on LFL.

The samples taken for measuring the bacterial count were prepared at four different dilution rates of 1:10, 1:100, 1:1000, and 1:10000 in accordance with a modification of the protocol described in the 9125 Heterotrophic Plate Count Method [23].

\section{Results and Discussion}

In the first round of de-coloring experiments, the RF inductance alone showed no effect whatsoever on the light absorption of the solution. The results of measuring the light absorption of the solution at various wavelengths by the spectrophotometer are shown in Table 4. As can be seen, no change has occurred with or without the HF device. 
Table 4. Light absorption of ink solution before and after RF inductance

\begin{tabular}{lccccc}
\hline Wavelength (nm) & $\mathbf{4 5 0}$ & $\mathbf{5 0 0}$ & $\mathbf{5 5 0}$ & $\mathbf{6 0 0}$ & $\mathbf{6 5 0}$ \\
\hline $\begin{array}{l}\text { Absorption (baseline scenario) } \\
\begin{array}{l}\text { Absorption after 90 min of RF } \\
\text { inductance (RF-aided scenario) }\end{array}\end{array}$ & 1.773 & 1.653 & 1.548 & 1.451 & 1.361 \\
& & 1.656 & 1.549 & 1.454 & 1.365 \\
\hline
\end{tabular}

That is why the second set of decolorization experiments were carried out, in order to test whether or not RF inductance could have any synergic effect with bleaching. Here, again, the use of the HF device did not lead to any substantial enhancement of color removal with $\mathrm{NaClO}$. In other words, the value of light absorption by the solution was more or less the same in both the baseline and the RF-aided scenarios, for both the visible and UV wavelength range. The results for the visible range are displayed in Table 5.

Table 5. Detailed results of the adsorption of the solution during continuous injection of liquid $\mathrm{NaClO}$ for both the baseline and RF-aided (HF) scenarios, showing no significant difference between the two.

\begin{tabular}{ccccccccccccc}
\hline \multicolumn{2}{l}{ Wavelength $(\mathbf{n m})$} & \multicolumn{2}{c}{$\mathbf{4 5 0}$} & \multicolumn{4}{c}{$\mathbf{5 0 0}$} & \multicolumn{2}{c}{$\mathbf{5 5 0}$} & \multicolumn{2}{c}{$\mathbf{6 0 0}$} & \multicolumn{6}{c}{ 650 } \\
\hline $\begin{array}{c}\text { Sample } \\
\text { number }\end{array}$ & $\begin{array}{c}\text { Time } \\
(\mathbf{m i n})\end{array}$ & Baseline & HF & Baseline & HF & Baseline & HF & Baseline & HF & Baseline & HF \\
\hline 1 & 0 & 1.778 & 1.782 & 1.662 & 1.67 & 1.561 & 1.567 & 1.467 & 1.472 & 1.377 & 1.376 \\
2 & 5 & 1.277 & 1.157 & 1.218 & 1.112 & 1.155 & 1.061 & 1.098 & 1.015 & 1.042 & 0.966 \\
3 & 10 & 1.004 & 1.047 & 0.953 & 1.002 & 0.911 & 0.973 & 0.887 & 0.941 & 0.858 & 0.897 \\
4 & 15 & 1.053 & 1.056 & 1.013 & 1.016 & 0.974 & 0.972 & 0.94 & 0.93 & 0.896 & 0.884 \\
5 & 20 & 1.056 & 1.009 & 1.005 & 0.964 & 0.964 & 0.925 & 0.922 & 0.885 & 0.889 & 0.858 \\
6 & 25 & 1.065 & 0.977 & 1.011 & 0.931 & 0.969 & 0.891 & 0.93 & 0.857 & 0.896 & 0.821 \\
7 & 30 & 1.063 & 0.958 & 1.005 & 0.913 & 0.966 & 0.878 & 0.925 & 0.839 & 0.889 & 0.798 \\
\hline
\end{tabular}

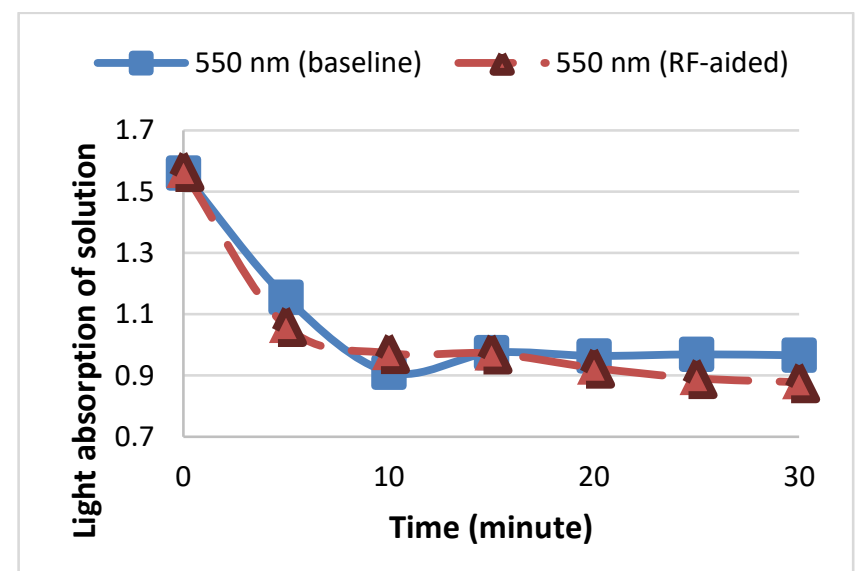

Figure 5. Visual comparison of changes in absorption of the water-ink solution, for baseline and RF-aided scenarios with continual injection of $\mathrm{NaClO}$.

Figure 5 visually demonstrates that, during the first 10 minutes or so, the $\mathrm{NaClO}$ proceeds to react with the ink regardless of whether the HF device is on or off and the extent of reaction is more-or-less the same; at times however, the RF-aided system may have had a very slight impact. These findings are in line with previously reported findings by Dimitrious et al. (2017) who also found that RF inductance alone had no effect on decolorization of dye aqueous solution. Moreover, in that study, it was shown that the use of the RF device had a very slight synergetic effect with ozonation of the solution [22]. Three commonly-used azo-reactive dyes (namely C.I. Reactive Yellow 84, C.I. Reactive Red 120 and C.I. Reactive Blue 198) were used in that study, and RF inductance showed a slight synergic effect with ozonation (5-10\% 
destruction of color) just in the first 15 min of experiment; while the values of color removal were almost the same in the remainder of the experiments [22].

In the UV range, no strong effect or difference could be observed between the baseline and RF-aided scenarios. This can be interpreted as no chemical reactions being affected by the presence of radio frequency inductance within the system. Following the observation that RF inductance was not successful at color removal, either in the presence or absence of an oxidizer, the study moved on to investigate the effect of RF inductance on coagulant floc formation and settling. The experiments were carried out as explained earlier, and after closely analyzing the recorded videos, it was concluded that RF inductance had no effect on coagulation or settling of the formed flocs. The results of these experiments are shown in Tables 6 and 7.

Table 6. Results of coagulant floc settling experiments using $\mathrm{FeCl}_{3}$ and $\mathrm{Ca}(\mathrm{OH})_{2}$.

\begin{tabular}{ccccccc}
\hline $\begin{array}{c}\text { Exp. } \\
\text { number }\end{array}$ & $\begin{array}{c}\text { Water } \\
(\mathbf{L})\end{array}$ & $\begin{array}{c}\mathbf{F e C l}_{\mathbf{3}} \\
(\mathbf{m l})\end{array}$ & $\begin{array}{c}\mathbf{C a}(\mathbf{O H})_{2} \\
(\mathbf{g})\end{array}$ & $\begin{array}{c}\mathbf{p H} \text { of } \\
\text { solution }\end{array}$ & $\begin{array}{c}\text { Did flocs form } \\
\text { and settle? }\end{array}$ & $\begin{array}{c}\text { Did RF inductance } \\
\text { have any effects? }\end{array}$ \\
\hline 1 & 7 & 42 & 30 & 7 & Yes & No \\
2 & 7 & 42 & 25 & 6.05 & Yes & No \\
3 & 7 & 42 & 20 & 5.2 & No & No \\
4 & 7 & 15 & 9 & 7.6 & Yes & No \\
5 & 7 & 15 & 8 & 6.6 & Yes & No \\
6 & 7 & 15 & 7 & 5.5 & No & No \\
\hline
\end{tabular}

Table 7. Results of coagulant floc settling experiments using $\mathrm{FeCl}_{3}$ and $\mathrm{NaOH}$.

\begin{tabular}{ccccccc}
\hline $\begin{array}{c}\text { Exp. } \\
\text { number }\end{array}$ & $\begin{array}{c}\text { Water } \\
(\mathbf{L})\end{array}$ & $\begin{array}{c}\mathbf{F e C l}_{3} \\
(\mathbf{m l})\end{array}$ & $\begin{array}{c}\mathbf{N a O H} \\
(\mathbf{m l})\end{array}$ & $\begin{array}{c}\text { pH of } \\
\text { solution }\end{array}$ & $\begin{array}{c}\text { Did flocs form } \\
\text { and settle? }\end{array}$ & $\begin{array}{c}\text { Did RF inductance } \\
\text { have any effects? }\end{array}$ \\
\hline 1 & 7 & 15 & 30 & 7 & Yes & No \\
2 & 7 & 15 & 25 & 6 & Yes & No \\
3 & 7 & 15 & 20 & 5 & No & No \\
\hline
\end{tabular}

In fact, two deductions were made after analyzing the recorded videos:

1. The rate of sedimentation of the suspended flocs in both scenarios (HF on or off) was the same, and the height of the sludge blanket from the bottom of the system container was equal at corresponding times.

2. The RF inductance was not able to alter the shape or texture of the $\mathrm{FeCl}_{3}$ flocs. More specifically, it did not break down flocs when they formed, nor did it help the formation of flocs when the conditions were not conducive to their formation.

Although it has been claimed in the HF patents that the HF device has effects on flocculation and can improve the settling rate of flocs [24], in this study, no effect was observed. This could be because only one type of coagulation was used (ferric chloride) in this study. In future studies, the effect of the HF on other flocs such as polyaluminum chloride could be explored. In addition, in the current study, the coagulant was used alone without the existence of suspended particles in the system. In other words, the coagulant was allowed to form flocs with itself. In systems where other solid particles exist, the interface between the coagulant and the suspended matter might be affected by the HF. After acknowledging that the use of the RF did not exhibit any suitable effects on color removal or floc formation, the study proceeded to test the effects of the HF device on leachate samples. Similar to the initial experiments on synthetic wastewater, RF inductance showed no effect on decolorization of leachate. However, results indicated that RF inductance can significantly reduce the bacterial count of the LFL. Table 8 
shows the result of the bacterial count of samples taken at various times with and without the HF device. Evidently, the use of the HF device leads to a marked reduction in bacteria.

Table 8. Bacterial count of leachate samples, comparison of baseline and RF-aided scenarios.

\begin{tabular}{cccc}
\hline pH & Time (minutes) & $\begin{array}{c}\text { Number of bacterial colonies in one ml of LFL (CFU/ml) } \\
\text { Baseline scenario }\end{array}$ & $\begin{array}{c}\text { RF-aided scenario } \\
7.7\end{array}$ \\
& 15 & $9.2 \times 10^{4}$ & $7 \times 10^{4}$ \\
& 45 & $9.2 \times 10^{4}$ & $6.4 \times 10^{4}$ \\
& 75 & $9.2 \times 10^{4}$ & $6 \times 10^{4}$ \\
\hline
\end{tabular}

As shown in Table 8 , the number of bacterial colonies in the untreated leachate was $9.2 \times 104$ $\mathrm{CFU} / \mathrm{ml}$ and remained the same if the HF device was off, regardless of the amount of time it circulated in the system. However, by using the RF induction on the leachate, the number of bacterial colonies in the leachate decreased to 7104 and then to 6.4104 and $6104 \mathrm{CFU} / \mathrm{ml}$ after 15, 45, and $75 \mathrm{~min}$, respectively. As a result, RF inductance could decrease the bacterial community by a quarter in the first 15 minutes and by about $35 \%$ depending on the induction duration. The results are visually shown in Figure 6. Based on the physical function of the HF device, the possible reason for the decrease in bacterial count can be speculated. By turning the $\mathrm{HF}$ on, RFs are induced in the liquid circulating in the system. RF waves rapidly oscillate from positive to negative with a mean voltage of zero. Thus, this oscillation can create zones in which the bacteria (cell bodies) in the water are alternatively positively and negatively charged. When particles such as bacteria or other suspended particles in the water have acquired a charge, water molecules adjacent to a bacterium orient and position themselves in such a way that a layer of water surrounds the bacterium. The result is that the cell membrane of the bacterium is subjected to osmotic pressure depending on the different concentrations of solute inside and outside of the membrane, which will eventually cause rupture of the membrane and the death of the bacterium [24].

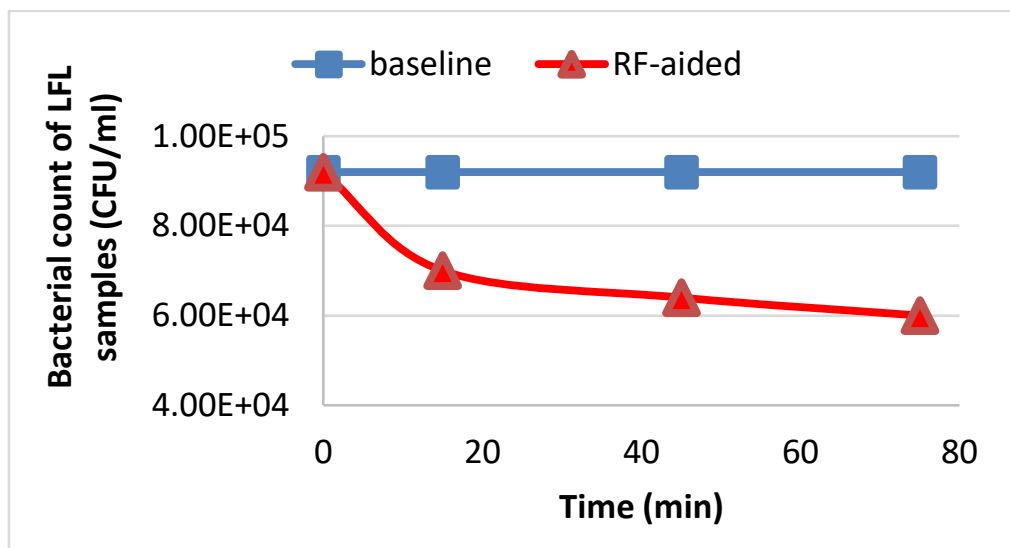

Figure 6. Changes in bacterial count during experiments on LFL, comparison of baseline and RF-aided scenarios.

Similar findings were reported in the study of Kim et al. (2011) when direct RF electric fields were applied to cooling water circulating in a heat exchanger. The RF electric field (3.5 MHz) could control bio-fouling (near-zero fouling level) while maintaining a bacterial count under targeted values of 10,000 CFU/ml and 100,000 CFU/ml in the bulk water and sessile samples, 
respectively [18]. Caubet et al. (2004) also found that radio frequency alternating electric current $(10 \mathrm{MHz})$ inductance can reduce the bacterial count of a solution. In that study, it was found that radio frequency inductance can enhance antibiotic efficacy against bacterial biofilm. This effect was like the traditional "bioelectric effect", in which direct electricity current is applied to medical wastewater in order to enhance anthibiotic efficacy; while radio frequency inductance has no direct contact with the wastewater [21] and is thus safer. By analyzing the results, it can be seen that in the first 15 min of the experiment, $24 \%$ of the bacterial community was killed; while, in the following $60 \mathrm{~min}$, only an additional $11 \%$ was added to the previous number. This hints at the idea that perhaps the marginal benefit of using RF for bacteria removal shrinks with longer residence times. Such findings will have to be further investigated and corroborated.

\section{Conclusions}

In the present study, the effects of RF inductance on decolorization, coagulation and sedimentation of flocs, and bacterial count were investigated. A HydroFlow-S38 device (Hydropath Holdings) was used to induce radio frequencies in liquid within the system. Results of the experiments on synthetic wastewater showed that RF inductance had no significant effect on the decolorization of the liquid. When used alongside an oxidant $(\mathrm{NaClO})$, again, the presence of the RF device had no sizable effect. These experiments were followed by an investigation of whether or not the RF device could have an impact on ferric chloride floc formation and settling. Using video recordings of floc formation and settlement at various $\mathrm{pH}$ levels, again, no visible differences could be observed when the RF device was used (compared to baseline tests without the RF). The volume of sludge forming from flocculation also showed no change. Finally, experiments were conducted on LFL samples collected from the Aradkooh waste processing and landfilling complex. Although RF did not aid LFL decolorization, it had a significant effect on the sample bacterial count. The number of bacterial colonies per $\mathrm{ml}$ of LFL decreased from $9.2 \times 104 \mathrm{CFU}$ for untreated leachate to $7 \times 104,6.4 \times 104$ and $6 \times 104$ $\mathrm{CFU} / \mathrm{ml}$, after 15,45 , and 75 min of RF inductance.

\section{Acknowledgments}

The authors would like to thank Mr. Rahbar, the manager of Radin Gostar Sina company for generously providing the HF device to the research team.

\section{Competing Interest}

All authors declared no competing interest.

\section{References}

[1] Martin, K.R.; Robey, N.M.; Ma, S.; Powers, L.C.; Heyes, A.; Schmitt-Kopplin, P.; Cooper, W.J.; Townsed, T.G.; Gonsior, M. (2021). Characterization of landfill leachate molecular composition using ultrahigh resolution mass spectrometry. Environmental Science: Water Research \& . Technology, 7, 1250-1266. https://doi.org/10.1039/D1EW00020A.

[2] Hu, Y.; Gu, Z.; He, J.; Li, Q. (2022). Novel strategy for controlling colloidal instability during the flocculation pretreatment of landfill leachate. Chemosphere, 287, 132051. https://doi.org/10.1016/j.chemosphere.2021.132051. 
[3] Bandala, E.R.; Liu, A.; Wijesiri, B.; Zeidman, A.B.; Goonetilleke, A. (2021). Emerging materials and technologies for landfill leachate treatment: A critical review. Environmental Pollution, 291, 118133. https://doi.org/10.1016/j.envpol.2021.118133.

[4] Teng, C.; Zhou, K.; Peng, C.; Chen, W. (2021). Characterization and treatment of landfill leachate: A review. Water Research, 203, 117525. https://doi.org/10.1016/j.watres.2021.117525.

[5] Yan, Z.; Jiang, Y.; Chen, X.; Lu, Z.; Fan, G.; Liang, H.; Qu, F. (2021). Evaluation of applying membrane distillation for landfill leachate treatment. Desalination, 520, 115358. https://doi.org/10.1016/j.desal.2021.115358.

[6] Pasalari, H.; Farzadkia, M.; Gholami, M.; Emamjomeh, M.M. (2019). Management of landfill leachate in Iran: valorization, characteristics, and environmental approaches. Environmental Chemistry Letters, 17, 335-348. https://doi.org/10.1007/s10311-018-0804-x.

[7] Warmadewanthi, I.D.A.A.; Zulkarnain, M.A.; Ikhlas, N.; Kurniawan, S.B.; Abdullah, S.R.S. (2021). Struvite precipitation as pretreatment method of mature landfill leachate. Bioresource Technology Reports, 15, 100792. https://doi.org/10.1016/j.biteb.2021.100792.

[8] Reshadi, M.A.M.; Soleymani Hasani, S.; Nazaripour, M.; McKay, G.; Bazargan, A. (2021). The evolving trends of landfill leachate treatment research over the past 45 years. Environmental Science and Pollution Resesarch, 28, 66556-66574. https://doi.org/10.1007/s11356-021-14274-x.

[9] Meier, J.; Remmen, K.; Wintgens, T.; Melin, T. (2021). Nanofiltration in Landfill Leachate Treatment. In Nanofiltration, 2ns Ed.; Schäefer A.I., Fane, A.G., Eds.; Wiley: Weinheim,Germany; pp. 663-690. https://doi.org/10.1002/9783527824984.ch15.

[10] Kwarciak-Kozłowska, A.; Fijałkowski, K.L. (2021). Efficiency assessment of municipal landfill leachate treatment during advanced oxidation process (AOP) with biochar adsorption (BC). Journal of Environmental Managemenet, 287, 112309, https://doi.org/10.1016/j.jenvman.2021.112309.

[11] Brasil, Y.L.; Silva, A.F.R.R.; Gomes, R.F.; Amaral, M.C.S.S. (2021). Technical and economic evaluation of the integration of membrane bioreactor and air-stripping/absorption processes in the treatment of landfill leachate. Waste Management, 134, 110-119. https://doi.org/10.1016/j.wasman.2021.08.013.

[12] Jagaba A.H.; Kutty, S.R.M.; Lawal, I.M.; Abubakar, S.; Hassan, I.; Zubairu, I.; Umaru, I.; Abdurrasheed, A.S.; Adam, A.A.; Ghaleb, A.A.S.; Almahbashi, N.M.Y.; Al-dhawi, B.N.S.; Noor, A (2021). Sequencing batch reactor technology for landfill leachate treatment: A state-of-the-art review. Journal of Environmental Managemenet, 282, 111946. https://doi.org/10.1016/j.jenvman.2021.111946.

[13] Zhang, L.; Bai, H.; Zhang, Y.; Wang, Y.; Yue, D. (2021). Life Cycle Assessment of Leachate Treatment Strategies. Environmental Science and Technology, 55, 13264-13273. https://doi.org/10.1021/acs.est.1c02165.

[14] Reshadi, M.A.M.; Bazargan, A.; McKay, G. (2020). A review of the application of adsorbents for landfill leachate treatment: Focus on magnetic adsorption. Science and Total Environment. 731, 138863. https://doi.org/10.1016/j.scitotenv.2020.138863.

[15] Xuefei, M.; Lan, X.; Jiapeng, C.; Zikang, Y.; Wei, H. (2013). Experimental study on calcium carbonate precipitation using electromagnetic field treatment. Water Science and Technology, 67, 2784-2790. https://doi.org/10.2166/wst.2013.161.

[16] Tijing, L.D.; Kim, H.Y.; Lee, D.H.; Kim, C.S.; Cho, Y.I. (2009). Physical water treatment using $\mathrm{RF}$ electric fields for the mitigation of $\mathrm{CaCO}_{3}$ fouling in cooling water. International Journal of Heat and Mass Transfer, 53, 1426-1437. https://doi.org/10.1016/j.ijheatmasstransfer.2009.12.009.

[17] Georgiou, D.; Bendos, D.; Kalis, M.; Koutis, C. (2018). Removal and/or prevention of limescale in plumbing tubes by a radio-frequency alternating electric field inductance device. Journal of Water Process Engineering, 22, 34-40. https://doi.org/10.1016/j.jwpe.2017.12.013.

[18] Kim, W.; Cho, D.J.; Cho, Y.I. (2011). Use of RF electric fields for simultaneous mineral and biofouling control in a heat exchanger. International Communication in Heat and Mass Transfer, 38, 1003-1007. https://doi.org/10.1016/j.icheatmasstransfer.2011.05.007.

[19] Rzeznik, L.J.; Juenke, M.S.; Stefanini, D.D.; Clark, M.; Lauretti, P. (2008). Two Year Results of a Breakthrough Physical Water Treating System for the. SPE International Oilfield Scale Conference, 317-327. https://doi.org/10.2118/114072-MS. 
[20] Inhibition of corrosion of structures. (accessed on May 2021) Available online: https://patents.justia.com/patent/20100101933.

[21] Caubet, R.; Pedarros-Caubet, F.; Chu, M.; Freye, E.; de Belem Rdigues, M.; Moreau, J.M.; Ellison, W.J. (2004). A radio frequency electric current enhances antibiotic efficacy against bacterial biofilms. Antimicrob Agents Chemother, 48, 4662-4664. https://doi.org/10.1128/aac.48.12.46624664.2004 .

[22] Georgiou, D.; Kalis, M.; Patermarakis, G.; Vassiliadis, A.A. (2017). Destruction of Azo-Reactive Dyes by Ozonation and the Synergetic Effect of a Radio-Frequency Alternating Electric Field Inductance Device. Current Trends in Fashion Technology \& Textile Engineering, 1, 42-47. https://doi.org/10.19080/ctftte.2017.01.555560.

[23] 9215 Heterotrophic plate count. (accessed on May 2021) Available online: https://www.standardmethods.org/doi/10.2105/SMWW.2882.188

[24] Fluid treatment method and apparatus. (accessed on May 2021) Available online: https://patents.justia.com/patent/8029669. terms and conditions of the Creative Commons Attribution (CC BY) license (http://creativecommons.org/licenses/by/4.0/). 